\title{
Sending States' Transnational Interventions in Politics, Culture, and Economics: The Historical Example of Italy
}

\author{
Mark I. Choate \\ Brigham Young University - Utah, mark_choate@byu.edu
}

Follow this and additional works at: https://scholarsarchive.byu.edu/facpub

Part of the History Commons

Original Publication Citation

International Migration Review 41, n. 3

\section{BYU ScholarsArchive Citation}

Choate, Mark I., "Sending States' Transnational Interventions in Politics, Culture, and Economics: The Historical Example of Italy" (2007). Faculty Publications. 1959.

https://scholarsarchive.byu.edu/facpub/1959

This Peer-Reviewed Article is brought to you for free and open access by BYU ScholarsArchive. It has been accepted for inclusion in Faculty Publications by an authorized administrator of BYU ScholarsArchive. For more information, please contact ellen_amatangelo@byu.edu. 
Sending States' Transnational Interventions in Politics, Culture, and Economics: The Historical Example of Italy ${ }^{1}$

Mark I. Choate

Brigham Young University

Abstract.

This article uses archival evidence to study in depth the historical policies of Italy, as a classic sending state. Most of the mass migrations of a century ago came from multinational empires, but Italy was a recently formed independent state. Ambitious to benefit from emigration while assisting and protecting emigrants, Italy reached out to "Italians abroad" in several ways. For example, the state opened a low-cost channel for remittances through a non-profit bank; promoted Italian language education among Italian families abroad; supported Italian Chambers of Commerce Abroad; and subsidized religious missionary work among emigrants. Italy's historical example of political innovation and diplomatic negotiation provides context, comparisons, and possibilities for rapidly changing sending state policies in the twenty-first century.

Article.

SENDING STATES PAST AND PRESENT

On 20 December 2001 the Italian Parliament extended the constitutional right to vote to Italian citizens outside Italy. Italians abroad now choose twelve of the 630 members of the (C) 2006 Mark I. Choate. All Rights Reserved. 
Chamber of Deputies and six of the 315 elected members of the Senate. One deputy and one senator come from each of the following continental groups: “Europe, including Russia and Turkey; South America; North and Central America; Africa, Asia, Oceania, and [even] Antarctica"; the rest of the expatriate seats are divided according to the density of Italian settlements worldwide. ${ }^{2}$ The candidates in each geographic division must be residents of that continent. After registering with their consulate, voters may mail in their ballots from countries in compliance with international agreements guaranteeing security of the post. If no such agreements are in force for the country of residence, Italians abroad may return to Italy to vote, with a $75 \%$ reimbursement for their travel. Italians abroad voted for the first time in the national referendum of June 2003 and in the parliamentary election of April 2006, when the expatriate vote was decisive in the center-left coalition victory. ${ }^{3}$

At first sight, this ambitious, worldwide program seems much like the extension of suffrage for expatriates from other nations, including Brazil, Mexico, Poland, and elsewhere (Levitt and de la Dehesa, 2003; Itzigsohn, 2000; Guarnizo, 1998; Committee on Migration, 1999). However, the struggle for the Italian vote abroad has a much longer history. It was proposed by the Socialist Parliamentary deputy Angelo Cabrini as early as 1908 (Cabrini, 1908). The voting rights legislation of 1913 expanded the rights of Italian males inside Italy, but Cabrini's proposals were discounted as impractical. After two world wars and the fall of Mussolini, suffrage for Italians abroad was proposed again by the neofascist Mirko Tremaglia, elected to the Chamber of Deputies in 1972. Tremaglia, who in 2001 became Italy's first "Minister for Italians in the World," claims credit for authoring the measure, but it actually (C) 2006 Mark I. Choate. All Rights Reserved. 
originated on the political left. What seemed infeasible a hundred years ago has won broad support in the twenty-first century. Tracing the Italian state's approach to expatriates helps reveal what is new and old in sending states' transnational relationships with their emigrants abroad.

Several scholars have noted the similarities between Italy's migration experience and the recent wave of world migrations (Gabaccia, 2000; Foner, 2000). However, other comparisons have been limited by unfamiliarity with Italian history (Smith, 2003b; Levitt, 2001b). Significant errors in chronology, cause and effect, Italian emigration policy under Liberalism and Fascism, and the role of the Italian state and Catholic Church in Italian emigration have plagued recent literature, principally because these issues have been neglected by historians. The last thorough investigation of Italian emigration policy in English was Robert Foerster's classic The Italian Emigration of Our Times (1919/1968). After the articles of Schmitter Heisler (1984, 1985), more recent works in English have focused on emigrants themselves and the networks they have developed, rather than the involvement of the Italian state. Social scientists posing different kinds of questions are left to read between the lines of histories written for other purposes, and are left to form flawed conclusions through no fault of their own. These errors mar what is otherwise excellent scholarship, as Italian emigration policy has been artificially separated into approaches for "homelands" and "global nations"; Italian "sojourners" are made categorically different from "transmigrants"; and Italy's historical example is excluded as a special case. These mistakes represent lost opportunities.

The present article aims to present an accurate, documented, and detailed historical (C) 2006 Mark I. Choate. All Rights Reserved. 
analysis of Italian state involvement in emigration. As the source of the largest international migration in recorded world history, the state of Italy offers striking comparisons for contemporary scholars and policymakers. The other mass transatlantic emigrations of a century ago departed from multinational empires: there was no Ireland to protect the Irish, no Poland for Poles, no Israel for Jews. Their British, German, Austrian, and Russian imperial rulers favored their respective ethnicities and had little incentive to protect expatriate minorities (Jacobson, 1995). By contrast, the Kingdom of Italy was a newly united state, formed in the nineteenth century from nine smaller states on the Italian peninsula, and emigration emerged as a decisive challenge and opportunity to define Italy's role on a world stage. The Italian state actively intervened in migration throughout the century from 1876 to 1976, as 26 million Italians emigrated abroad, a figure never surpassed in recorded history (Vecoli, 1995). Italian politicians struggled to react to an escalating population exodus, eventually moving toward policies to encourage remittances, promote Italy's reputation, and frame emigrants as "Italians abroad."

Studying state actions does not here imply taking the nation-state for granted (Wimmer and Glick Schiller, 2003). The Italian nation-state was a consciously artificial construction built between 1859 and 1871; as the painter/novelist/statesman Massimo D'Azeglio famously remarked, "unfortunately we have made Italy, but are not making Italians" (D'Azeglio, 1867:1:7; Soldani, 1993). Despite its obvious lack of authenticity or historical tradition, Italy as a sending state exerted a powerful influence at key points in the migration process, particularly in the conditions of departure and possible return. The following historical sketch of Italian transnational intervention aims to set the apparent "absolute uniqueness" of recent migrations (C) 2006 Mark I. Choate. All Rights Reserved. 
in comparative context (Fredrickson, 1995:604; cf. Appadurai, 1996).

Bridging the humanities and the social sciences, history has much to offer the rapidly changing field of migration studies. Several scholars have commented on the difficulty of integrating historians' perspectives with social science research, as historians are often bound by the locality of context and individual experience (Diner, 2000; Morawska, 2003). The gulf between generalizing theories and historical specificity can seem insurmountable, particularly when studying the development of immigrant communities. Yet history and the other social sciences have much in common when the focus is emigration and the continuing involvement of sending states. Theory is much more applicable here. The Italian state, as we shall see, was highly interested in social science theory, which informed Italian emigration policies. And Italian state policies are naturally comparable to the policies of states with similar concerns. Italian politicians themselves studied other countries' contemporary policies in detail when crafting the Italian state's landmark emigration legislation of $1901^{4}$. The problems Italian observers raised, and how they addressed them, reveal a perspective and policy framework that may inform the study of international migration in the twenty-first century.

Relationships between sending states and expatriates seem more vibrant and controversial now than ever before. Debates focus on the rights and responsibilities of states and "their" citizens beyond their borders, and what all stand to gain and lose (Lopez-Guerra, 1995; Smith, 1997, 1998b, 2003b). As the twentieth century saw the expansion of universal male and female suffrage within state borders, the twenty-first century has seen the extension of voting rights to emigrants living outside the borders of the state. Besides voting, sending (C) 2006 Mark I. Choate. All Rights Reserved. 
states have pursued a subtle range of economic, cultural, and political ties with expatriates. Mexico has sought out its Mexicans abroad (Mexicanos de afuera); India cultivates ties with non-resident Indians (NRI); the Philippines reach out to Overseas Filipino Workers (OFW), or, as in President Gloria Macapagal-Arroyo's optimistic rendering, “Overseas Filipino Investors” (OFI) (Massey, 1999; Steller, 2002). From the perspective of the sending state, these emigrants remain still fundamentally Mexicans, Indians, and Filipinos, whatever their citizenship or adopted nationality. How might this relationship continue to evolve? What are the interests involved on both sides? Can states build sustainable relationships with expatriates?

Most of Italy's emigration occurred between 1880 and 1914, a period comparable to the early twenty-first century. These decades were a period of isolated wars, (relative) international peace between world powers, and uneven economic prosperity. Although Italy was a large, respected, and powerful state in Europe, it was still undergoing significant economic development, struggling to catch up with its competitors. ${ }^{5}$ Italy trailed well behind Germany, the United States, Britain, and France in the economic indicators of the day (Kennedy, 1987). Millions of Italians left Italy in search of better economic opportunities not only in the United States, but across North and South America, western and central Europe, the Mediterranean basin, Africa, and Australia. I calculate the population of Italians abroad in 1911 as roughly onesixth of the population of the Italian peninsula itself (Gribaudi, 1913; ISTAT, 1976). Despite its unique aspects, Italy's emerging position in international affairs a century ago may be compared with large nations such as Mexico and India today. This helps explain a striking convergence in their policies towards emigration, particularly in economic and cultural affairs (C) 2006 Mark I. Choate. All Rights Reserved. 
(Levitt and de la Dehesa, 2003; Pessar, 1988). State-sponsored institutions promoting solidarity among emigrants, including language education, cultural festivals, and ethnic holidays, help create community dynamics which encourage remittances, be it in the twentieth or twenty-first centuries (Marcelli and Lowell, 2005:73, 96-97).

A century ago, breakthroughs in travel and communications technology opened unprecedented possibilities for international emigrants to connect with their countries of origin.

By today's standards, of course, steamships and telegraphs are obsolete, but their introduction cut transatlantic travel time from months to days, and the exchange of messages from days to hours. The cost of travel plummeted dramatically, coming within the reach of more and more people. The relative advances seemed to bring about a new age, comparable to the impact of later twentieth-century advances in travel from days to hours, and in communications from hours to fractions of a second. The excitement of discovering "transnationalism" was evident back then, as the pathbreaking thinker Randolph Bourne proposed in 1916 the idea of a "TransNational America." Bourne imagined that nationalism would be replaced by multiple transnational loyalties, and that a new culture could be fused from immigrant contributions (Bourne, 1916; Vaughan, 1991). What the Italian American journalist Gino Speranza wrote in 1906 rings familiar today:

commercial interests, the "annihilation of time and space" by improved methods of transportation and the ebb and flow of travel, will render the old distinctions of nationalities and the parochial character of present-day patriotism, more and more an (C) 2006 Mark I. Choate. All Rights Reserved. 
anachronism. The conception of citizenship itself is rapidly changing and we may have to recognize a sort of world or international citizenship as more logical than the present peripatetic kind, which makes a man an American while here, and an Italian while in Italy. (Speranza, 1974:310)

Why did Bourne's and Speranza's visions not become reality? The two world wars and the Cold War limited the advances of communications technology in a divided world. But in the twentyfirst century, spurred by the incentive of remittances, sending states will likely accomplish more than ever before in building transnational relationships with their expatriates abroad in a multicultural information age.

\section{FRAMING THE CHALLENGE OF EMIGRATION}

From the perspective of Italian writers, politicians, and government officials, mass emigration emerged in the 1880 s as a major challenge for the new state. What were the terms of political debate? How could the state attempt to intervene? With time, the Italian state's approach changed dramatically. Emigration policy remained highly controversial and hotly debated, with only a fragile consensus of support, but the Italian legislature and bureaucracy shifted aims completely from restricting emigration to advancing the cause of emigrants. The single greatest catalyst in this change was statistical rigor. State leaders wisely invested in careful statistical monitoring of emigration flows. Emigration debates and emigration policy moved from emotional overstatements to calculated, measurable reforms in proven programs.

(C) 2006 Mark I. Choate. All Rights Reserved. 
The debate began as a moral dilemma: was emigration good or bad? Landowners and employers warned that the exodus of agricultural workers would undermine Italy's agricultural economy and rural society. The Italian state's first forays into emigration aimed for police enforcement of blanket restrictions (Choate, 2008). Two regulations issued by Internal Ministers in 1873 and 1876 were so restrictive that they encouraged clandestine emigration from French and Austrian ports outside Italian control (Ostuni, 2001). State-sponsored attempts to block emigration thus proved ineffective. But Parliament's first law on emigration, passed in 1889, maintained a focus on domestic regulation by police. Emigration agents, who earned commissions on transoceanic tickets, were blamed as the root cause of mass migration because they painted deceptive pictures of life abroad and defrauded emigrants en route. Deputies in Parliament also criminalized emigrants themselves. A Venetian count opined that many emigrants were escaping their debts and overdue rents; another deputy claimed many emigrants were seeking fortune and adventure, instead of working for a living ${ }^{6}$. Even though curbing individuals' freedom to emigrate undermined the principles of Italian Liberalism, such restrictions were easily excused.

Yet the policing of emigration by the Italian Internal Ministry failed miserably, as domestic priorities often counteracted international concerns. Italian police had every incentive to encourage troublemakers to emigrate, particularly if their crimes were suspected but not proven. Mismanagement of emigration helped lay the foundation for organized crime in Italian communities abroad, with tremendous damage to Italy's international reputation (Filipuzzi, 1976). Only through sustained argument could the discussion of emigration move beyond a (C) 2006 Mark I. Choate. All Rights Reserved. 
moralizing debate that condemned emigrants as reprobates. The Liberal economist Francesco Saverio Nitti, whose native southern region of Basilicata produced disproportionate emigration, posited that the people must emigrate or turn to crime: "either emigrants or brigands" (Nitti 1888/ 1958:1:364, 337). Monsignor Giovanni Battista Scalabrini, Bishop of Piacenza, declared that emigration "is a law of nature.... a source of welfare for who goes and who stays.... It can be good or bad for the individual or nation, depending upon its conditions" (Scalabrini, 1899:23). Italy's second emigration law of 31 January 1901 was a watershed in the Italian state approach to expatriates. The legislation aimed to shape conditions for emigrants and protect them from exploitation, through unprecedented state intervention in all aspects of international travel (Whelpley, 1905). In a reversal of previous policy, emigration became the responsibility of the Italian Foreign Ministry and its new Emigration Commissariat, charged with protecting and developing emigrants' italianità and funded by a new passport tax. Fundamental rights to emigrate, and to expect Italian state protection abroad, were enshrined in the new law.

Another key debate, closely related to whether emigration was "good" or "bad," centered on the difference between "temporary" and "permanent" emigration. At first, statisticians and politicians divided emigration into two categories: "As is known, Italian migration is of two kinds ... the first is of persons who plan to go abroad in search of work for a more or less brief period; the second, of those who travel abroad to work for an indefinite time" (Direzione Generale della Statistica, 1899:v). This categorical division depended upon the individual emigrant's plans; local mayors simply asked people what destination to write on their (C) 2006 Mark I. Choate. All Rights Reserved. 
passports. Transatlantic migration was assumed to be permanent, while migration within Europe and the Mediterranean was thought to be temporary. Employment for a few months just beyond Italy's borders was "good" because it provided wages for Italian families, and drew upon centuries-old traditions of seasonal migrations; but permanent emigration across the ocean, a recent phenomenon facilitated by new transportation technologies, was "bad," a complete loss.

This distinction soon broke down. An Italian might plan to work in France temporarily but, not finding work, might emigrate to the Americas from the ports of Marseille or Bordeaux, and then return home to Italy after five years. An exhaustive census by Italian consuls of Italians abroad in 1901, published in nine volumes as Emigrazione e colonie [Emigration and colonies], challenged categorical thinking by describing the Italians in Tunisia as a "permanent" colony and in Argentina as a "temporary" colony, since few Italians had become Argentine citizens (Commissariato dell’Emigrazione, 1903-1909:2:2:331, 3:2:209; Choate, 2007). By 1904 the Italian government finally conceded that the geographical distinction between permanent and temporary emigration was completely arbitrary, and statisticians divided migration simply into transoceanic and European/Mediterranean (Direzione Generale della Statistica, 1904, 1908). This was a major conceptual shift. Emigrants were not "lost" or "absent"; careful tallies of passenger lists over decades showed that about half eventually returned to Italy (Commissariato Generale dell'Emigrazione, 1926). Still officials in the United States clung to the notion that transoceanic immigrants had come to stay permanently (Wyman, 1993).

(C) 2006 Mark I. Choate. All Rights Reserved. 
For Italy, statistics were the crucial factor in understanding mass emigration. The state invested significant resources in gathering, analyzing, and distributing scientific statistics on population movements. The first Italian Commissioner of Emigration, appointed in 1901, was Luigi Bodio, an accomplished statistician who had organized the first census of Italians abroad in 1871 (Bodio 1873, 1882). The Emigration Commissariat's monthly bulletin [Bollettino dell'emigrazione] was primarily a statistical and academic compendium (indexed in Cordasco, 1980). Unlike comparable government publications in Britain and Germany, which addressed emigrants themselves with tips and advice, the Italian publication included lengthy reports with statistical, legislative, historical, and anecdotal material from Italy and a wide array of foreign countries, written by consuls, professors of the social sciences, and emigration officials.

Statistics on all aspects of migration and remittances were printed by month, quarter, year, and decade. Drawing upon the Bollettino, Socialist and Catholic charities produced and distributed their own emigrant manuals, filled with practical advice for their followers who might emigrate.

Girded with carefully gathered statistical evidence of the fluidity between categories of long-distance and short-term, temporary and permanent, Italians developed a flexible migration theory, collapsing the traditional categories of emigrant, exile, and expatriate into a single group of "Italians abroad" (italiani all'estero), located in emigrant "colonies" (colonie) settled around the world. It was counterproductive, if not futile, to make practical distinctions between rich exporters traveling first class, emigrants traveling in steerage, and Italians abroad for indefinite employment or for a short visit, since individuals readily crossed between groups. All could be reached by a simplified policy supporting Italian culture and identity among Italians (C) 2006 Mark I. Choate. All Rights Reserved. 
abroad (cf. Smith, 1998b). In 1887, for example, prime minister Francesco Crispi ordered Italian consuls to celebrate the birthdays of the King and Queen of Italy with the entire expatriate community, not just the wealthy:

I am persuaded that too often the colony is not for the Consul that great family that it should be. . . every diplomatic or consular Official must work to set up relationships of this nature toward all the colony in the place of his residence, not just toward an elect part of it. . . The festival of the Constitution [Statuto] and the liberation of Rome [20 September 1870], and the birthdays of the King and of the Queen, are the four festivals that I would like to see celebrated, by the royal Agents and by the colonies together in all solemnity. ... inviting everyone from the colony, without distinctions of class or wealth, because these celebrations should be designed to fellowship everyone.

(Filipuzzi, 1976:170-172)

With the dramatic geographical and financial mobility of Italians scattered worldwide, and with high return migration, the more friends of Italy the better. The Italian state aimed to cultivate loyalty and sentimentality [italianità] among all Italian expatriates in a mutually beneficial relationship, intervening "from above" to cultivate "transnationalism from below" (Guarnizo and Smith, 1998; Levitt, 2001a; Portes and Jensen, 1987).

What could serve as the basis for an international Italian community? Italy had been founded upon a Romantic idea of national identity, originally embracing Italian-speaking subjects under the rule of nine different states. Most Italians were united in the Kingdom of Italy by 1871 , but some Italians remained in the Austro-Hungarian Empire: Italy's resurgence (C) 2006 Mark I. Choate. All Rights Reserved. 
("Risorgimento") was incomplete. Into the twentieth century, nationalist dreams continued to cut across borders to claim as subjects everyone speaking the Italian language. In reality, when Italy was created few spoke the official Italian tongue, which academics had crafted from Sienese and Florentine dialects; but patriots could gloss over the mutually unintelligible regional languages of, for example, Lombardy, the Veneto, Sicily, Naples, and Liguria. Italian culture supposedly stood as one, transcending borders of states or regional traditions, and Italian expatriates in Europe, the Mediterranean, and the Americas were all arranged together as "Italians Abroad" in expositions, censuses, and guidebooks (Bodio, 1873; Ministero degli affari esteri, 1884; Benvenuti, 1890; Esposizione Generale Italiana, 1899; Barbèra, 1906). The claims for a common cultural denominator for all Italians everywhere became a centerpiece for flexible and multivalent policies, pioneered by the Italian government.

With ongoing concern for Italians abroad, the Italian state avoided the term "diaspora," or scattering. Rather, through state support for emigrants, Italians at home and abroad could in theory be united in a "Greater Italy," styled after J. R. Seeley's idea of "Greater Britain," expanded beyond its state borders by its worldwide population (Seeley, 1883). Pietro Gribaudi's school textbook of 1913, La più grande Italia [Greater Italy] presented this rhetoric to students in graphic form. The cover showed the globe wrapped in a long Italian flag, under the rays of the Star of Italy. This national symbol thus became a guiding light, a point of reference for Italians scattered around the world, but figuratively part of a single community. Gribaudi exhorted both patriotic pride and concern for Italian emigrants:

(C) 2006 Mark I. Choate. All Rights Reserved. 
There is no country on earth where some Italian does not live. This thought, while it must arouse in us the feeling of great and high destinies to which the Italian nation is called, must drive us to forget not our faraway brothers, who, with their honest labor, powerfully advance a knowledge and appreciation of Italy in every corner of the globe. These our brethren merit all of our affection and, in case of need, our assistance.

(Gribaudi, 1913:8)

Gribaudi taught that emigration resulted from Italy's greatness, as a contribution and reflection of Italian dynamism. The idea of diaspora, on the other hand, could evoke statelessness and the loss of political autonomy, anathema to the young and fragile Italian state. Worries over Italy's international prestige stoked heated debate. Were emigrants members of a "Greater Italy," or exploited "worker bees" supporting Italy's national competitors? The political agitator Enrico Corradini, who founded the Italian Nationalist party and rallied support for Benito Mussolini's Fascism against Italian Liberalism, condemned Italy's support for emigration in 1909: “The Jews of antiquity always mourned their emigration which they called dispersion, diaspora. But we have become used to boasting of it. ... this appears a sign of our blindness and meanness of spirit, from which the Jews did not suffer" (Corradini, 1923:73). Some scholars today have applied the term "diaspora" to Italian emigration in this period, but this supports Corradini's critique that the Italian state did nothing for its scattered children abroad, just as if an Italian state did not exist. In response to Corradini, Italian Liberals pointed to the government's attempt to stand at the center of an international expatriate community, drawing from its strength and providing guidance and organization, like a hub in the center of a wheel. ${ }^{7}$ (C) 2006 Mark I. Choate. All Rights Reserved. 
What did this debate mean in practical terms? Were Italians abroad still part of Italy, or not? The question was complicated by Brazil's unilaterally declaring that all residents and immigrants were automatically Brazilian citizens, unless they explicitly declared their opposition. Could Italians lose their citizenship even without their knowledge? Under mounting pressure from Nationalists and conservatives, the Italian Parliament compromised with its citizenship law of 1913. Drawing upon organic, Romantic ideas of national identity, the legislators specifically forbade dual nationality: "stating the phrase 'double citizenship' is enough to understand its absurdity.... No cell in the physical world can belong at the same time to two different organisms; likewise, no citizen in the moral world can belong to two different political units." ${ }^{8}$ By law, if emigrants adopted Brazilian or American citizenship, they could not claim consular protection as Italian citizens. But the law openly encouraged return migration, with easy renewal of full citizenship. Upon return to Italy, emigrants would regain their Italian citizenship either by their declaration or automatically after a short period of residence. This policy is illustrated in the case of Gaetano Salvemini, a Radical who fled in 1934 from the Fascist regime to the United States, and returned home to Italy in 1948 after the war. After careful thought, he decided to relinquish his American citizenship after four years of residence in Italy. To his surprise, he had already regained Italian citizenship two years previously! (De Caro, 1970) Italian emigrant children of the second generation, and even grandchildren of future generations, could hold foreign citizenship by birth on foreign soil (jus soli) but still claim Italian citizenship by blood (jus sanguinis). And all Italians and their descendants, no matter their (C) 2006 Mark I. Choate. All Rights Reserved. 
citizenship, were counted in the censuses of Italians abroad (Direzione Generale della Statistica, 1901-1904).

Italy's clever approach to expatriate citizenship obviated the need for a distinction in status between temporary and permanent emigrants. This flexible policy offered clear benefits to emigrants and to the Italian state, as argued by the economist Francesco S. Nitti: "our emigrants in the Americas must renounce their Italian citizenship, and at the same time become more patriotic Italians" (Nitti, 1896:17). Italians abroad could take on Brazilian citizenship (even if against their will), or French citizenship (to be eligible for employment in public works projects), or any other foreign citizenship with its immediate advantages, and still not lose their Italian nationality or their access to Italian citizenship. ${ }^{9}$ For example, Italy's diplomats in the United States openly encouraged their co-nationals to adopt U.S. citizenship and participate fully in local elections, thereby strengthening Italy's international influence. At the same time, these citizens were not lost to the Italian state. Rather, the state encouraged them with incentives to return home to Italy for retirement, with full benefits of their native citizenship. While they were abroad and hailed as "Italian" rather than by regional or provincial monikers, emigrants were encouraged to buy Italian goods, learn standard Italian and teach it to their children, and promote Italian culture.

Italy's approach accomplished many of the same objectives as the straightforward dual citizenship offered by many countries in the twenty-first century (Guarnizo, 2001).With this flexible idea of "Italians abroad," embracing not just citizens but everyone worldwide speaking (C) 2006 Mark I. Choate. All Rights Reserved. 
Italianate languages, or with Italian ancestry, the Italian state laid the groundwork for a nuanced program of emigrant support, embracing economics, language, and religion.

\section{STATE-SPONSORED INSTITUTIONAL STRUCTURES}

To reach out to emigrants worldwide, Italy pushed the limits of state action, working outside the traditional sphere of "politics" (Portes, 2001) by using proxies and cultural alliances. Several states with significant Italian immigration, such as the United States, opposed any intervention by sending states. Theodore Roosevelt argued, for example, "we have no room for any people who do not act and vote simply as Americans, and as nothing else" (Roosevelt, 1897:26). Foreign influence could stir up the "melting pot" of Americanization, from which immigrants were to emerge as pure Americans. Faced with official restrictions by host nations on contacts with Italian emigrants, the Italian state increasingly worked through unregulated cultural channels to support its expatriates. Italy avoided the United States' ban on schools sponsored by foreign states, for example, by subsidizing religious schools which would teach Italian to illiterate emigrants and their children. When the United States forbade an Italian official from aiding migrants at Ellis Island, Italy relied upon Catholic, Socialist, and Protestant charities to spread the message that an Italian consular agency was located nearby and could assist newly arrived immigrants.

By working with non-governmental organizations abroad to reach its emigrants, the Italian state gave up a great deal of control. Emigrants could be influenced only indirectly, through social and cultural ties. A useful analytical concept here is Jürgen Habermas's idea (C) 2006 Mark I. Choate. All Rights Reserved. 
(1989) of a "public sphere" [Öffentlichkeit], beyond state regulation and based on open discourse. The Italian state attempted to support, but could never control, an "international public sphere" of Italian emigrants worldwide. Italy offered incentives to make it easy for emigrants to act in ways beneficial to the Italian state, by indirectly subsidizing remittances and return migration, and tried to monitor the success of such activities with accurate statistics. Regulating Italian activity abroad was impossible, and was vigorously rejected by host nations in the Americas and in Europe. Investing resources in the hands of intermediaries seemed the only choice for action, but carried significant risks. After emigrants had been hailed as Italy's representatives abroad, what if they embarrassed the Italian government? Nevertheless, Italy could benefit directly from its indirect investments in an international community of Italians abroad. Arguably, it is in a sending state's interest to encourage international exchange and discourse with emigrants, even if the dynamics are beyond the state's control.

Italian intervention in migration currents was hotly debated not just in receiving countries such as the United States and France, but in Italy also. Was support for emigrants encouraging more emigration? Even laissez-faire Liberalists who agreed on the need to help emigrants disagreed about how best to do so. What was the state's responsibility in supporting emigrants abroad? How might emigrants best be prepared for success? Controversies in Italy sometimes paralleled debates in receiving countries, such as the proposals in the United States Congress to ban the immigration of illiterates. Congress passed this measure three times but failed to overturn a presidential veto in 1897,1913 , and 1915 , before finally defeating the veto and enacting the Literacy Test in 1917 (Zolberg, 2006). In Italy, Professor Ausonio Franzoni (c) 2006 Mark I. Choate. All Rights Reserved. 
proposed in Parliament that Italy enact a preemptive ban on the emigration of illiterates. He said this would be for their own good, since migrants unable to read and write were notoriously exploited (Italian Colonial Institute, 1910:1:149-151). Another writer called for what might be termed a "brain drain," asking underemployed lawyers, teachers, and journalists to emigrate and lead expatriate colonies of unskilled and semi-skilled workers (Penne, 1906:703-704). But few agreed on how best to tap and organize emigrants as a resource.

Through compromise, close public scrutiny, and unceasing debate, the Italian state became involved in several key fields of emigrant life. By coordinating institutional efforts in Italy and abroad, the state was able to intervene with some success in the economic, cultural, and religious dynamics of migration, through Italian Chambers of Commerce Abroad; a dedicated government agency, the Emigration Commissariat; ties to Catholic orders serving emigrants, such as the Scalabrinians; special channels for remittances through the non-profit Banco di Napoli; and organized Congresses, Expositions, and conferences of Italians Abroad, held across Italy to publicize and celebrate the connections between expatriates and their homeland.

Italian Chambers of Commerce Abroad

Italy founded its first Chambers of Commerce Abroad in 1883, the same year as France and other European countries, but Italy's chambers focused uniquely on emigrants as a target market. Stakes were high. From Italy's perspective, emigrants could serve as a "bridgehead" consumer base for Italian exports in big international markets, particularly Argentina and the (C) 2006 Mark I. Choate. All Rights Reserved. 
United States. But if expatriates did not buy Italian products abroad, and instead produced cheap, Italian-style goods behind tariff barriers overseas, this new competition could ruin entire sectors of the national economy. The Italian Chambers of Commerce Abroad served as the front line in this international economic competition. Unlike United States Chambers of Commerce, which are independent and sometimes highly critical of the U.S. government, the Italian Chambers were actual representatives of the state, entrusted with advising the nation's export interests. The Foreign Ministry ordered its consuls to establish and support Chambers of Commerce wherever possible; they were maintained with subsidies from the Ministry of Commerce and used official government symbols, including the flag and royal seal of the Kingdom of Italy. ${ }^{10}$ The Chambers Abroad also coordinated with the Union of Chambers of Commerce in Rome, a network representing more than forty cities in Italy. Across the peninsula, and across the world, Italian Chambers of Commerce exchanged products for "commercial museums" to display goods available for import and export through Italian traders (Mozzarelli and Nespor, 1985). By 1911, Italian Chambers of Commerce had been established in Sao Paolo, Mexico City, Montevideo, Buenos Aires, and Rosario, Argentina; Berlin, London, Paris, Marseille, Bruxelles, and Geneva; Constantinople and Smyrna (Istanbul and Izmir), Tunis, and Alexandria; San Francisco, New York City, and Chicago, and later in Boston, New Orleans, and San Antonio (Italian Colonial Institute, 1911a; Italian Chamber of Commerce in New York, 1937). Before the First World War, the Chambers organized four international congresses, held in Rome in 1901, Paris in 1911, Brussels in 1912, and Naples in 1913, to coordinate common policies. The Chambers called for local and international tariff reform, improved shipping, the (C) 2006 Mark I. Choate. All Rights Reserved. 
establishment of Italian credit unions abroad, and the lowering of international postal rates (Italian Chamber of Commerce in Belgium, 1913).

The Italian Chambers of Commerce Abroad aspired to act as catalysts for strong and lasting communities of Italian expatriates. Certainly, creating an Italian identity abroad served the direct interests of professionals, such as Italian doctors and accountants who would have a ready customer base, and of importers, now called "transnational entrepreneurs" (Portes, Guarnizo, and Haller, 2002), who could supply the Italian cheeses, tomatoes, oils, and wines necessary for authentic Italian cuisine. An Italian Uruguayan newspaper argued passionately in favor of the local Italian Chamber, recently formed in 1883: "Let no one be distanced from the moral and material benefits, which our Fatherland carries to far-off lands. We do not want the Chamber of Commerce to be a caste; we want it to unite all laborers who love the Fatherland and want to honor it." ${ }^{11}$ In Tunis the Chamber's biweekly newspaper, L'Unione, became a rallying standard for the interests and identity of the local Italian community, particularly in resisting encroachments on Italian rights by the French colonial government. ${ }^{12}$

By subsidizing the creation of social networks through the Chambers of Commerce Abroad, the Italian state helped to organize emigrant communities and improve their chances of success. More connections and more networks allowed migrants to compete more effectively in a range of economic markets. The Chambers built upon the natural communities created through chain migration, but also increased exchange and communication among immigrants from different provinces and regions, in pursuit of an "Italian" colony, rather than smaller and more vulnerable "Sicilian" or "Lombard" colonies, or even smaller units divided by (C) 2006 Mark I. Choate. All Rights Reserved. 
home villages. Italy's transnational activity helped create social capital for its emigrants, according to the definition of Pierre Bourdieu: "the aggregate of the actual or potential resources which are linked to possession of a durable network of more or less institutionalized relationships of mutual acquaintance or recognition" (Bourdieu, 1985:248; Portes, 1998). State investment in Chambers of Commerce as sites of ethnic formation and group solidarity would turn, it was hoped, into financial returns in the form of increased Italian exports, and increased remittances and return migration back to Italy, with a host of accompanying positive effects (Levitt, 1998; Light et al., 1994).

The phrase "social capital," while useful for contemporary comparisons, was of course not employed a century ago. The theorist who captured the attention of Italian politicians at the start of the twentieth century was Luigi Einaudi, a young economist and author who later became the first President of the Republic of Italy after World War II. Italian debates had long focused on emigration's good/bad, moral/unethical qualities; in his book A Merchant Prince (1900), Einaudi argued along lines similar to Bourdieu, that it was in Italy's interest to build a cultural network for expanded trade. He argued that "trade follows the footsteps of the emigrant; but not all emigrants, only those who even after many generations preserve relations of affection and interest and social customs with the land in which they or their ancestors were born" (Einaudi, 1900:10). With an upbeat narrative, Einaudi described the success of one Italian "merchant prince," Enrico Dell'Acqua, who marketed textiles to Italian immigrant "colonies" and established a dominant position in the South American market. As Dell'Acqua demonstrated, emigration could help Italy overcome its international competition: (C) 2006 Mark I. Choate. All Rights Reserved. 
It is the logic of little minds to believe that every factory established by our compatriots, every piece of cultivated land, every hill planted with vines in America represents a subtraction from our activity, a net loss for Italian exports. In reality, those local products accredit Italian brands and awaken latent desires, and as tastes become more refined, the market turns from imitations made by Italians to genuine Italian products. (Einaudi, 1900:146, 160)

Emigration was more than so many people leaving and so many coming back: it could open a new era for Italian growth. In Einaudi's vision, Italian Chambers of Commerce Abroad played a natural role in building an export market upon the expanding base of Italian expatriates. Einaudi used classical economic theory to build confidence in Italy's mass emigration. He argued that entrepreneurs like Dell'Acqua represented "the living incarnation of the intellectual and organizational qualities destined to transform today's 'little Italy' into a future 'greater Italy,' peacefully expanding its name and its glorious progeny in a continent more vast than the ancient Roman Empire" (Einaudi, 1900:18). Other social scientists took up Einaudi's call for a new approach to emigration, building upon its strengths rather than decrying its failures.

Bolstered by these concepts, in 1901 the Italian Parliament enacted sweeping legislation to shift emigration policy towards a national foreign policy priority.

\section{Emigration Commissariat}

Italy's landmark emigration legislation of 1901 was unprecedented in its ambitions (Whelpley, 1905). Not only would steamship travel agents and shipboard conditions be tightly (c) 2006 Mark I. Choate. All Rights Reserved. 
controlled, but the state also took responsibility for regulating all aspects of the emigration experience, up to disembarkation at the foreign port. Even more, Italy announced its intent to protect and support its expatriates beyond Italian borders. This was a complete break from previous legislation. The 1901 law created the Emigration Commissariat to shepherd the nation's interests in migration abroad, under the auspices of the Italian Foreign Ministry.

The Commissariat's main task was to implement and administer the new law. Its agents inspected the Italian ports of Genoa, Naples, and Palermo, and traveling inspectors went to foreign ports and expatriate settlements. The Commissariat posted maximum prices for thirdclass fares, and enforced strict regulations for safety, food, water, air, light, and living space aboard passenger ships. Italian naval physicians inspected hygienic conditions aboard every emigrant ship, at the carrier's expense. Independent emigration agencies were banned; only steamer companies could obtain licenses for agents to sell tickets, and the licenses could be revoked if the steamers were unsafe. Emigrants gained more rights in disputes with steamer companies; they received refunds if they missed a voyage because of late trains or a sickness in their family, and free room and board if the voyage was delayed. If they were rejected at foreign ports, such as the United States' Ellis Island, they returned home at the carrier's expense. Tickets could be sold in Italy only for departure from Italian ports and from Le Havre, France, which was more convenient to some parts of northern Italy. Carriers' protests were to no $_{\text {avail. }}{ }^{13}$

Going well beyond the traditional reach of government, the Commissariat also took up the responsibility to protect Italians before and after their emigration. The Commissariat (C) 2006 Mark I. Choate. All Rights Reserved. 
organized hospices in Italy for departing emigrants, and subsidized charities, cultural groups, and hospitals for Italians abroad. All of these activities were funded by a new tax of eight lire (\$1.60) per third-class berth, levied on steamer companies but paid by emigrants themselves. The resulting Emigration Fund grew enormously, much faster than the Commissariat could spend it, as Italy's transatlantic emigration reached all-time record levels after 1902, peaking at more than half a million emigrating to the Americas in 1906 and 1913 (Commissariato Generale dell'Emigrazione, 1926). The Emigration Fund was subject to an annual parliamentary debate, keeping Italy's migration policies under regular public scrutiny.

Proponents of Italy's migration programs a century ago based their interventions upon a range of social sciences, including demography, economics, and sociology. Mass migration even contributed directly to the formation of a new discipline, Italian ethnography, by the pioneering anthropologist Lamberto Loria. Like many European ethnographers, Loria specialized in studying "exotic" and colonial cultures at the beginning of his career. In 1905, however, on his way to the Italian Colonial Congress in Eritrea, he stopped at a small village in Campania and was struck by the originality of the local crafts and traditions. Upon returning from Africa, Loria encountered a group of emigrants on their way to Naples, wearing their best traditional dress to make a favorable impression on migration inspectors. He realized that while he had traveled at great expense to study the cultures of Eastern Africa and Papua New Guinea, he knew little of the rich and varied traditions in his native Italy (Loria, 1912). Loria founded a Museum of Italian Ethnography in 1907, and organized the First Italian Ethnographic Congress in 1911. There his associate Francesco Baldasseroni called for a broad, complex, and thorough study of (C) 2006 Mark I. Choate. All Rights Reserved. 
Italian expatriate cultures, investigating links to the emigrants' native communities and measuring the influence of host societies. This would provide a cultural cartography for solving the problems of "Greater Italy":

We must ask ourselves: how far do the millions of Italians who abandon the Fatherland preserve their customs and traditions, or at what point do they accept foreign traditions? Where is the adaptation of emigrants the easiest? And when do the changes happen? Are Northern or Southern Italians more tenacious in maintaining their customs and habits?. . this ebb and flow of population, that goes abroad and returns home periodically, how does it change and when does it destroy local traditions? These people in a continual double relationship between their civilization and a foreign civilization: what elements do they most tenaciously preserve of theirs and what do they accept of the other? (Baldasseroni,1912:179-181)

Such a study had obvious economic implications for Italy. For emigrants to maintain their customs and habits they would require Italian exports, particularly culinary exports of wines, cheeses, vegetables, and other authentic products. By positing an ebb and flow of population, Baldasseroni could argue convincingly that the emigrants had not left "Italy" at all; they were its representatives overseas, an integral part of Italian society and culture. The Emigration Commissariat now had a scientific justification for its interest in Italians outside Italian state borders.

Identifying emigrants as ethnographically "Italian" helped mobilize greater support within Italy for expatriates abroad, who might otherwise have seemed anonymous, (C) 2006 Mark I. Choate. All Rights Reserved. 
renunciatory, and distant. The President of the Italian Colonial Institute, for example, called for greater coordination among emigrant settlements, via "an organization among the population colonies in the great ethnographic empire, which our people could have in the world, replacing the divided Italic members with a powerful vital organism, pulsing with the heartbeat of a vigorous national life." ${ }^{14}$ The scientific study of emigrant ethnography, with its vision of expanding Italian influence and resources, helped justify state investments in subsidizing schools and cultural activities, as well as charitable assistance for Italians abroad. Such subsidies promoted what would now be termed "social capital development" and "ethnic niche economies" among Italian emigrants a century ago.

Transnational efforts proved much more successful for Italy's Liberal government (especially before 1918) than for Fascist Italy. Benito Mussolini, himself a former emigrant to Switzerland, worked assiduously after becoming prime minister in 1922 to promote a renewed freedom of international migration following the Great War. Mussolini organized a major international migration congress in 1924, attempting a reconciliation between the needs of countries of emigration and immigration (Commissariat General, 1925). These efforts came to naught. Italian emigrants were rejected everywhere in a world-wide wave of isolationism, spearheaded by the United States. Ever the clever propagandist, Mussolini turned his failure around and declared that Italians no longer needed to emigrate; he disbanded the Emigration Commissariat in 1927. The Fascist regime also attempted to "fascisticize" groups of Italians abroad, but ultimately only brought discredit upon itself and its supporters abroad (Ostuni, 1978; Finkelstein, 1988).

(C) 2006 Mark I. Choate. All Rights Reserved. 


\section{Religious Institutions}

From the 1880 s onward, the Catholic Church hierarchy in Italy was keenly concerned about massive emigration, particularly the stories of abuse and exploitation of Italian Catholics abroad (Rosoli, 1996). Emigration threatened to break apart marriages and families, dissolve traditional morality, and undermine Italian society and health. Return migration threatened to bring Protestantism, tuberculosis, alcoholism, and even anarchism from urban North and South America to the Italian countryside. Leaving emigrants to their fate could bring disaster; the Church needed to intervene in assisting and protecting Italians abroad, if only to protect the future of Italian society (Brown, 1995).

Church and State were at odds in the Kingdom of Italy, because the Liberal government had seized Rome and the Papal States between 1860 and 1871 amid a wave of anticlericalism (D’Agostino, 2004). In emigration, however, interests coincided, and church and government officials could cooperate productively in an informal partnership. A signal accomplishment of Italian emigration policy in the early twentieth century was the creation of an alliance of support from many sectors of Italian society, including religious orders.

The pioneer in Catholic assistance to emigrants was Monsignor Giovanni Battista Scalabrini, Bishop of Piacenza. Scalabrini felt that open antagonism between Church and State brought more harm than good, and favored collaboration to resolve Italy's most pressing problems. Pope Leo XIII asked Scalabrini in 1885 to write an anonymous pamphlet exploring a possible reconciliation between the papacy and the Italian state. The pamphlet drew vicious (C) 2006 Mark I. Choate. All Rights Reserved. 
attacks from intransigent clerics, and Leo never allowed Scalabrini to acknowledge his authorship (Francesconi, 1985). Bishop Scalabrini found more success in reaching out to Italian emigrants. By the mid-1880s he realized that a tenth of his diocese had emigrated from Italy. In 1887 Scalabrini wrote to the missionary body in Rome, Propaganda Fide, and began to organize a network of priests and nuns to aid Italian emigrants in Italy and the Americas. He also publicized his ideas and plans in a widely distributed pamphlet, Italian emigration in America, stressing that emigration was a consequence of economic want, not irresponsible fortuneseeking. This crisis demanded the attention and protection of the Italian Church and State cooperating together:

Religion and fatherland, these two supreme aspirations of every good heart, become intertwined, become complete in this work of love, which is the protection of the weak, and fuse together in a marvelous harmony. The miserable barriers, erected by hate and anger, disappear . . . every distinction of class or party withdrawn. . . . May Italy, sincerely reconciled with the Apostolic See, emulate its ancient glories and add a new, undying glory, setting even its faraway children on the shining paths of true civilization and progress. (Scalabrini 1887/1997:35)

Scalabrini's project was well received in Rome by the papacy and by the state. Pope Leo XIII in 1888 issued the Apostolic Letter Quam Aerumnosa, based on a draft by Bishop Scalabrini, calling upon American bishops to support Scalabrini's programs, which included the Christopher Columbus Missionary Institute and the Missionary Congregation of St. Charles Borromeo, and by 1895 a supportive lay St. Raphael Society and also the Missionary Sisters of St. Charles (C) 2006 Mark I. Choate. All Rights Reserved. 
Borromeo. In 1914 Pius X founded the Pontifical College for Italian Emigration, and Benedict XV

created the Prelate for Italian Emigration in 1920. Bishop Scalabrini campaigned publicly for better emigration legislation (Scalabrini 1888, 1899), and can be credited with part of the success of the emigration law of 1901.

The Congregations of Scalabrinians worked with bishops in North and South America to support Italian migrants, especially by creating Italian-language parishes in centers of Italian settlement (Brown, 1996). A major part of the Scalabrinians' work was to study and explain the needs of immigrants in their new environments. Others followed Scalabrini's lead, such as Bishop Geremia Bonomelli of Cremona, who established a missionary congregation for Italian emigrants in Europe based upon more systematic cooperation with lay politicians (Rosoli, 1999; Confessore, 1971). The Opera Bonomelli, however, would not survive the Fascist era; because of compromising ties to state programs for the "fascisticization" of Italians abroad, Pope Pius XI dissolved the group in 1927 (Cannistraro and Rosoli, 1979). The Scalabrinians, by contrast, have thrived into the twenty-first century as an active missionary order (Cahill, 2004).

While Bishop Scalabrini worked to build Catholic programs among emigrants, his younger brother Angelo Scalabrini worked within the Italian government to build alliances with Catholicism. After 1896 Angelo worked as inspector general, and later director, of the Italian Schools Abroad Program. This program, founded in 1862, had started with very expensive Italian state-run schools scattered around the Mediterranean Basin and Middle East, teaching young Arabs, Jews, Greeks, Turks, and Albanians in areas where Italy hoped to build its influence. Massive Italian emigration to the Americas called the program into question, as many (C) 2006 Mark I. Choate. All Rights Reserved.
Deleted: The Vatican later created additional institutions, including the Pontifical College for Italian Emigration, founded by

Deleted: in 1914 as a specialized seminary

Deleted: , established by

Deleted: Benedict XV 
emigrants were illiterate or semiliterate, yet received no Italian support. The old program could not simply expand, though, as the United States, France, and other countries banned foreign states from opening schools in their territories. With Angelo Scalabrini, the state program changed direction, offering subsidies to religious and secular schools abroad that taught the Italian language to emigrants and their children. Aid consisted of cash, as well as books and curricular materials which stressed the greatness of Italy and its culture. With less expense to the Italian state, religious schools for emigrants and their children were often more successful than the secular schools, as noted by Luigi Villari, Italian vice-consul for emigration in Philadelphia:

parish schools are the best means for maintaining Italian language and feelings among emigrants, because the priests have influence on the children and families outside school. I can certify from experience that the parish schools really teach Italian and establish patriotic sentiments. The results are certainly more profitable than the products of any other schools or lay institutions, which have the life cycle of mushrooms. $^{15}$

Not only did parish schools benefit materially and spiritually from teachers pledged to poverty rather than salary, but the subsidized Italian schools abroad promoted a cultural resonance throughout their local migrant communities.

The Italian Schools Abroad Program and the Emigration Fund proved a neutral ground where Liberals, Socialists, Radicals, and Catholics could participate in aid for emigrants. Outside Italy, the Italian state could enlist the open support of Catholic clergy, including Salesians and (C) 2006 Mark I. Choate. All Rights Reserved. 
Franciscans, who had no other connections with the normally anticlerical, Liberal state (Trincia, 2002). Mother Frances X. Cabrini explained to her friend Leone Reynaudi, Commissioner for Italian Emigration, how she could in good conscience accept Italian state money to build the Columbus Hospital of Chicago: "You know that the Emigration funds are a private company, although under the auspices of the government, but one does not have to have recourse to the government. If it were government money, I would not take it” (Sullivan, 1992:213). Humanitarian organizations of reformist Socialists, and the heavily Liberal Dante Alighieri Society, also drew upon Italian state funding to help emigrants in central Europe.

The Italian state aimed not to support culture for culture's sake, but to use education as a cultural bond tying expatriates to the fatherland. Foreign Minister Sidney Sonnino noted with satisfaction in 1916 that in Argentina's classrooms, "instead of teaching grammar, the study of Italian literature will be obligatory, as this is considered more appropriate for communicating the glories of Italy." ${ }^{16}$ Subsidizing culture might also bring a clear economic return, as noted by Giuseppe Prezzolini:

as Dante and the Italian language become better known, more Italian products will be sold; in fact, as the prestige of Italian art, history, and literature increases, so much will increase the number of Americans who travel to Italy, who start using Italian products, who become used to Italian tastes and who, after returning home to America, will remain clients of Italian cooking and fashions. ${ }^{17}$

(C) 2006 Mark I. Choate. All Rights Reserved. 
Such grand economic aims, of course, were far from the ministry of Bishop Scalabrini and Pope Leo XIII. But economic returns for Italy were probably the most persuasive argument for state support of expatriates.

\section{Channels for Remittances}

Cash sent home by expatriates has always offered one of the most obvious, tangible, and far-ranging benefits of emigration. Yet even remittances were hotly debated in Italy. Would this money from abroad lead to structural changes in the Italian economy so emigration would no longer be necessary in the future, or would it act as a crutch, an artificial boost that in effect would prevent meaningful economic reform? Contemporary criticisms of international remittances follow the same lines (Russell, 1986; De la Garza, 2000).

In the late nineteenth century, Italy's flow of remittances was unmeasured and unregulated, so the impact was a matter of polemical conjecture rather than rational analysis. Migrants were poorly connected to any banking system. Instead of opening accounts with regulated banks, many entrusted money to the impromptu operations of private bankers, saloon keepers, and even bootblacks. While many immigrant bankers were honest, scoundrels gave all Italian bankers a bad name by delaying transfers, speculating with deposits, declaring bankruptcy, or practicing flagrant fraud. Immigrants had little redress, for the same reason they went to the illegal bank in the first place: local officials did not understand their dialects. Bank fraud among immigrants was very difficult for local governments to prosecute, since absconders usually fled the country and immigrants rarely testified before authorities. Italians (C) 2006 Mark I. Choate. All Rights Reserved. 
in large colonies at least enjoyed a competitive choice between bankers, but Italian bankers in small settlements usually exercised a monopoly, often controlling even the local post office (Soldaini, 1969). The tragic loss of emigrants' funds, after years of work and savings abroad, was another reason for Italian politicians to oppose unrestricted emigration.

The turning point was the law for the "protection of the remittances and savings of Italian emigrants abroad," enacted by Parliament on 1 February 1901, a day after the creation of the Emigration Commissariat. By law the non-profit Banco di Napoli, founded in 1539 as a charitable credit institution for southern Italy, contracted with the Italian government to transfer remittances from the Americas to Italy at special rates. Inexpensive "emigrant money orders" purchased at contracted banks overseas could be cashed in Italy at all local offices of the Banco di Sicilia, Banca d'Italia, all Italian post offices, and of course the Banco di Napoli. To limit the competition between the Banco di Napoli and private banks, and to focus the Banco on money transfers, Parliament did not allow the Banco to extend loans or issue currency overseas (Balletta, 1972). The bank did offer special rates for currency exchange at the port of Naples and at all of its branches, and opened its own limited-service agency in New York City after a wave of American bankruptcies in the Panic of $1907 .^{18}$

How did the Banco di Napoli win support for its emigrant money orders? It was in the obvious interests of the sending state, Italy, to become involved in the efficient and reliable transmission of emigrant remittances; the interests of the United States and other immigrantreceiving nations were less obvious. But banking regulators in New York and New Jersey welcomed the involvement of the Banco di Napoli in migrant banking, as it could provide (C) 2006 Mark I. Choate. All Rights Reserved. 
greater stability, reduce criminal activity, and improve the reputation of banks among immigrants (see Bair, 2005:101). Predictably, the illegal bankers protested the Banco's intervention in emigrant communities, mobilizing regional prejudices, conspiracy theories, and false accusations through the Italian-language press abroad (De Rosa, 1980). To limit popular opposition, the Banco selected reputable banks within emigrant communities to act as its corresponding representatives overseas, such as the Banco de Italia y Rio de la Plata for Argentina and the Banca Italo-Americana of San Francisco for the Pacific United States. Despite initial delays and setbacks with correspondent banks, the Banco di Napoli quickly streamlined its services.

In hindsight, this network was established just in time for Italy's unprecedented flows of emigration. Thanks to centralized remittances, the Italian government could now gauge the flow of money from emigrant colonies. Statistics on remittances from the Banco di Napoli held pride of place in the Emigration Commissariat's exhaustive reports, and helped to justify the importance of mass migration for Italy. In 1902, its first year of activity, the Banco processed 9.3 million lire in remittances. Volume nearly tripled to 23.6 million lire in the following year, soon reaching a consistent annual level of 84 million lire. After 1916, because of wartime inflation and currency fluctuations, remittances soared to a peak of 980 million lire in 1920 . The Italian Parliament had intervened to fight injustice, but the Banco created a smooth system for remittances that facilitated an unprecedented capital transfer into the Italian economy from the boom in Italian migration to the United States. Economic historian Luciano Cafagna calculates that from 1901 to 1913, tourism provided one-third and emigrant remittances one(C) 2006 Mark I. Choate. All Rights Reserved. 
half of Italy's "invisible credits" of 12 billion lire, a decisive factor in stabilizing Italy's balance of payments and preventing currency inflation during a major spurt in industrialization (Cafagna, 1973).

Remittances became a significant part of the Italian economy. Based on Banco di Napoli statistics, I calculate remittances as at least 1.5\% of Italian GDP in 1911, 1.35\% in 1919, and 1.45\% in 1920 (Commissariato Generale dell'Emigrazione, 1926; Istituto centrale di statistica, 1958). This is comparable to the place of remittances in Mexico's economy, which I calculate from CIA World Factbook data as $1.66 \%$ in 2004. Such percentages are the tip of an iceberg of economic services, trade relations, and multiplier effects. In addition, Italian emigrants continued to send money home through international money orders, which were indistinguishable from commercial transactions, and through untraceable regular mail, and to carry money home on their persons. The Banco di Napoli's network, however, provided the most reliable financial means for the emigrant and the most transparent transmission for the state and for later historians.

Italy's success in sponsoring a non-profit channel for remittances stands in stark contrast to the international financing available to migrants in the twenty-first century. Migrants today send more than $\$ 100$ billion annually by commercial wire services, which have overcharged their vulnerable clients by millions of dollars. ${ }^{19}$ In 2004 , the United States, together with the G8 and International Monetary Fund, called for greater transparency and lower fees in the channels for international remittances (Bureau of International Information Programs, 2004; de Luna Martinez, 2005; International Monetary Fund, 2005; Department for (C) 2006 Mark I. Choate. All Rights Reserved. 
International Development, 2005). Perhaps the international, non-profit work of the Banco di Napoli, commissioned by the Italian state to transfer remittances, can serve as an example of funneling emigrant remittances through legitimate banks, with the benefits of low costs, clear accounting, and managed risks.

\section{Celebrations of Italians Abroad}

How could successful emigrants represent themselves back home in Italy? How could the dry statistics of remittances be understood as real-life triumphs of Italians abroad? Many writers and politicians continued to believe that emigration was bad, despite the arguments of Liberal economists, anthropologists, and radical politicians. To address these concerns, a series of exhibitions and congresses featuring Italians abroad, held from 1892 to the First World War, served as public platforms not just for expatriates, but for Italians in the fatherland who argued for continued support of emigrants and emigration.

Expositions of Italian emigrants were notable not only for their embrace of emigration, but for their broad support from across the political and social spectrum. Liberals, Socialists, Catholics, and Freemasons among Italian communities overseas presented themselves as united in form and substance. The emigrants were keen to be understood as successful representatives of Italy abroad, not the desperate, castoff rejects of caricature. At first, Italian emigrant communities themselves organized festivals in Buenos Aires and London in 1881 and 1888 , to celebrate their achievements and to interact with local communities from a position of prestige. ${ }^{20}$ The first exhibition of emigrants within Italy itself was organized for the (C) 2006 Mark I. Choate. All Rights Reserved. 
quadricentennial of Columbus's voyage, at the 1892 Italian-American Exhibition in Genoa, followed by the 1898 pavilion of Italians Abroad at the National Exposition in Turin, and the 1906 Exhibition of Italians Abroad in Milan, sponsored by the city's International Exposition (World's Fair) (Cavagnari, 1893; Guida ufficiale, 1898; Frescura, 1907).

As part of these celebrations on the national and international stage, subsidized by the Italian state, the pavilions for Italians Abroad graphically displayed emigrants' achievements and documented the spread of Italian culture. Expatriates participated vicariously by sending in photographs of their local businesses, social clubs, churches, and local monuments, both new and ancient, built by Italians. Spearheaded by the local Italian Chambers of Commerce Abroad, special committees in emigrant communities prepared handsome bound volumes of statistics and anecdotes of success against great odds, together with models, posters, and other displays. The organizers in Italy and abroad took pains to present emigration as a national movement, without the regional and provincial divisions plaguing the peninsula after a millennium of political fragmentation. Many of the other pavilions in these expositions, featuring crafts and industrial products, inevitably highlighted regional diversity and belied the "national" label. Such diversity indirectly heightened the effect of the emigrants' pavilion, as emigrants from all over Italy were carefully presented as one body. As a result of attending the 1898 exposition, and reading the Argentine emigrants' album, Luigi Einaudi was inspired to write his groundbreaking study of emigrant economics, A Merchant Prince (1900), which in turn helped build support for the emigration law of 1901. Another writer offered his impressions of the 1906 exposition in Italy's leading cultural journal: "the Italian abroad feels the need to preserve (C) 2006 Mark I. Choate. All Rights Reserved. 
tight intellectual and economic ties with the Mother Country in order to feel always as a son or daughter, and to be able to return and live without the feeling of having become a foreigner" (Barbèra, 1906:450). Italians visiting the pavilions, seeing the products and triumphs of Italian emigrants worldwide, could be persuaded of the virtues of supporting emigration.

Even more emblematic of transnational cooperation were the First and Second Congresses of Italians Abroad, sponsored by the Italian Colonial Institute in 1908 and 1911 . The Colonial Institute, itself founded in 1906 and relying heavily upon Italian state subsidies, viewed emigration as Italy's prime success in colonial expansion (Choate, 2003). By 1911, the Institute had established permanent organizations in New York City, Philadelphia, Sao Paolo, Vienna, Constantinople, Alexandria, and Cairo, to reach and represent the most important and influential "colonies," certainly more influential than Italy's territorial colonies of Eritrea or Somalia. The two congresses of expatriates in Italy's capital were intended as forums not only for heralding expatriate accomplishments, but also for raising awareness of the obstacles facing emigrant workers, with the aim of influencing Italian policy. The plan was to test the congresses as a venue for the representation of Italian citizens abroad; if the experiment succeeded, perhaps emigrants could play a role in Parliament (Italian Colonial Institute, 1910, 1911b). But the issue of parliamentary representation for emigrants was derailed by the Italo-Turkish war of 1911-12, and even more so by the First and Second World Wars. Suffrage for Italian expatriates became law only in the twenty-first century.

\section{CONCLUSIONS}

(C) 2006 Mark I. Choate. All Rights Reserved. 
Of course, there are significant differences between the international migrations of the early twentieth century and those of the early twenty-first century. The European empires of the nineteenth and twentieth centuries have not survived; with their fall, many of the competitive assumptions behind foreign relations have also disappeared. Immigration regulations have changed significantly, in the United States and elsewhere, severely limiting legal immigration while indirectly encouraging illegal immigration (Zolberg, 2006). Italian officials carefully monitored decades of growing American prejudice against immigrants and shifting policy debates, until the U.S. Congress finally shut down Southern and Eastern European immigration in 1924. Since the Second World War, receiving countries have often planned for immigrants to depart after they have worked for a certain number of years as "guests" (Gastarbeiter). The massive wave of emigration a century ago also came from multiethnic empires, in contrast to the many independent states today which intervene in migration currents. Italy's unusual historical example, as a source of mass emigration while also an independent country, remains valuable today, principally in the innovative ideas, theories, and programs employed by a classic sending state.

In theory and practice, Italy dissolved the distinction between temporary and permanent emigrants. Emigrants themselves could not predict what category they would fall into (Cerase, 1974; Jones-Correa, 1998). "Permanent" emigrants could decide at any time to return to Italy, and they were welcome, especially with all their savings from abroad. Given the high rate of return migration, government programs to boost Italian loyalties abroad served domestic, as well as international, priorities for Italy's stability and reputation. Not only (c) 2006 Mark I. Choate. All Rights Reserved. 
remittances, but the promotion of the Italian language, emigrant community organizations, and expatriates' safety and welfare were significant concerns for Italy, as they are for other sending states (Niño Rodríguez, 2002; Østergaard-Nielsen, 2003). Italy moved well beyond traditional international diplomatic affairs to intervene directly and indirectly in constructing transnational networks (cf. Portes, 2001).

Italy's status as a large, but still developing state, may be the reason its programs resemble the policies of major sending states today. States develop similar programs in the face of similar incentives and challenges. Such programs for expatriates become more effective if consciously compared to historical and contemporary models. Italy's approach to dual citizenship has been influential in Latin America (Jones-Correa, 1998). Like Italy, both Mexico and Brazil have invested in the culture and economic status of their expatriates, by distributing books and literature, subsidizing literacy training, conducting censuses of emigrants abroad, and publishing competitive exchange rates (Levitt and de la Dehesa, 2003). Mexican, Dominican, and other countries' consuls and political parties have from time to time actively organized among key settlements of co-nationals overseas, risking dramatic backfire in the pursuit of lucrative international returns (Balderrama, 1986; Smith, 1998b, 2003a; Enriquez, 2005; Graham, 1997). Like the Congresses of Italians Abroad organized through the Italian Colonial Institute, South Korea supports an Overseas Koreans Foundation, Communist China sponsors a festival for overseas Chinese youth, and India has instituted "Pravisi Bharatiya Divas," an annual Overseas Indian Festival to bring home wealthy expatriates (Sharma, 2003; Louie, 2000; Bergsten and Choi, 2003). (C) 2006 Mark I. Choate. All Rights Reserved. 
The most outstanding success of Italy's outreach policies a century ago was in the field of remittances. Scholars and legislators designing solutions for migrants' money transfers in the twenty-first century may benefit from studying the non-profit Banco di Napoli's programs. The Italian Parliament contracted with this charity specifically to intervene in the remittance market abroad, prohibiting the bank from offering loans, mortgages, and other services. As the bank worked hard to build a network of bilingual correspondents in Italian migrant communities across the Americas, the Italian Foreign Ministry promoted financial literacy and education through its consulates and in emigrant hospices, emphasizing the benefits of trusting the Banco di Napoli rather than unlicensed private bankers (see Orozco and Wilson, 2005). In times of economic crisis and natural disaster, as in the aftermath of the earthquake of 1908, the Italian state launched specific fundraising efforts abroad in coordination with the Italian Red Cross. As emigrants gained confidence that their precious funds were securely transmitted, guaranteed from abuse, and well spent, they sent more and more money, and more money reached its destination than ever before, thanks to the Banco di Napoli's low fees. Italy also offered incentives for return migration through its citizenship policies. The promise of eventual return encouraged continued remittances, because emigrants avoided severing economic ties with their native land.

Italian state policies in support of emigration were always contingent and open for debate, both in Italy and abroad. Not until 2001 was suffrage available for Italians outside Italy. Consensus proved fragile in the face of contradictory aims and assumptions. Should Italian emigrants assimilate into foreign societies, if this served their interests? Did emigration really (C) 2006 Mark I. Choate. All Rights Reserved. 
reflect the expansion of Italian greatness worldwide? Many Liberals answered yes, but their opponents answered no. The anti-emigration Italian Nationalist Association was founded in 1911, with Italy at peace and Italian emigration at a peak. Partisan domestic politics, rather than changes in world affairs, likewise drove anti-immigration policies in the United States, Argentina, and Australia (Rosenblum, 2003). But the unilateral breaking of international migration networks certainly raised the likelihood of international war, which still stands as a lesson today.

Much scholarly debate has focused on the novelty of transnationalism in the twentyfirst century, and multi-layered transnational state involvement has been suggested as one new development (Guarnizo, 2003; also Bauböck, 2003; Vertovec, 2004). Yet the Italian state intervened in the newly developing "trans-nationality of all the nations" a century ago (Bourne, 1916:96), working to influence emigrants' culture, loyalties, and finances, in a sustained attempt to raise itself to the ranks of wealthy nations. Novelty does not add or take away any value or importance from transnational exchanges. Rather, Italy's policies provide a very relevant point of historical reference for better understanding migration trends today and into the future. Italy's outreach to "Italians abroad," regardless of their citizenship, mirrors the flexible programs of India, Mexico, and other states to retain or recruit the support of expatriates and their descendants on the basis of culture or ethnicity rather than legal nationality. Italy's emigration is a specific historical example which contributes directly to theoretical discussions of transnational developments. The benefit is clear: ideas from the past may suggest approaches and policies for the future. Italy's nonprofit banking channel for (C) 2006 Mark I. Choate. All Rights Reserved. 
remittances, and its involvement in cultural and religious programs for expatriates, could be a model for other countries of emigration, who now have access to better communications and broader possibilities for action in a multicultural world. Knowledge of Italy's historic transnational policies may also be useful in defending against political opposition to transnationalism in countries of immigration. Comparing sending states past and present, and looking at emigration as well as immigration, offers a path for better understanding between history and the other social sciences in the field of migration studies.

(C) 2006 Mark I. Choate. All Rights Reserved. 


\section{REFERENCES}

1898 Guida ufficiale della Esposizione Nazionale e della Mostra di Arte Sacra. Torino: Roux Frassati e $C$.

1937 Nel Cinquantenario della Camera di Commercio Italiana in New York. 1887-1937-XVI. New York: Italian Chamber of Commerce in New York.

Appadurai, A.

1996 Modernity at large: Cultural dimensions of globalization. Minneapolis, Minn.: University of Minnesota Press.

Bair, S. C.

2005 "Improving the Access of Recent Latin American Migrants to the U.S. Banking System." In Beyond Small Change: Making Migrant Remittances Count. Ed. D. F. Terry, S. R. Wilson. Washington, D.C.: Inter-American Development Bank. Pp. 95-132.

Baldasseroni, F.

1912 "Come si devono studiare gli usi e costumi dei nostri emigrati." In Atti del Primo Congresso di Etnografia italiana, Roma 19-24 Ottobre 1911. Ed. Società di Etnografia Italiana. Perugia: Unione Tipografica Cooperativa. Pp. 179-82.

Balderrama, F. E.

1982 In Defense of La Raza: The Los Angeles Mexican Consulate and the Mexican Community, 1929 to 1936. Tucson: University of Arizona Press.

Balletta, F.

1972 II Banco di Napoli e le rimesse degli emigrati, 1914-1925. Napoli: Institut Internationale d'histoire de la Banque.

Barbèra, $P$.

1906 "Gli italiani all'estero all'Esposizione di Milano," Nuova Antologia, 210, 126 of series 5: 440-50.

Bauböck, R.

2003 "Towards a political theory of migrant transnationalism," The International Migration Review, 37: 700-23.

Benvenuti, L.

1890 Dizionario degli italiani all'estero. Firenze: G. Barbèra.

(C) 2006 Mark I. Choate. All Rights Reserved. 
Bergsten, C. F., and I. Choi, eds.

2003 The Korean diaspora in the world economy. Washington, DC: Institute for International Economics.

Bodio, L.

1873 Sul censimento degl'italiani all'estero eseguito al 31 dicembre 1871. Relazione alla Giunta Centrale di Statistica. Roma: Barbèra.

1882 Statistica della emigrazione italiana all'estero. Roma: Società Geografica Italiana.

Bommes, M., and E. T. Morawska, eds.

2005 International migration research: constructions, omissions, and the promises of interdisciplinarity. Aldershot, England: Ashgate.

Bourdieu, P.

1980 "Le capital social: notes provisoires," Actes de la recherche en sciences sociales, 31: 2-3.

1985 "The forms of capital." In Handbook of Theory and Research for the Sociology of Education. Ed. J. G. Richardson. New York: Greenwood. Pp. 241-58.

Bourne, R. S.

1916 "Trans-National America." In Atlantic Monthly, pp. 86-97

Brown, M. E.

1995 Churches, Communities, and Children: Italian Immigrants in the Archdiocese of New York, 1880-1945. New York: Center for Migration Studies.

1996 The Scalabrinians in North America (1887-1934). New York: Center for Migration Studies.

Bureau of International Information Programs, U. S. Department of State

2004 Global Poverty Action Plan Approved by G8 Leaders, http://usinfo.state.gov (June 9, 2004)

Cabrini, A.

1908 Il Partito Socialista Italiano e la politica dell'emigrazione. Xo Congresso del Partito Socialista Italiano (Firenze, 19-22 Settembre 1908). Roma: Tipografia Popolare.

Cafagna, L.

(C) 2006 Mark I. Choate. All Rights Reserved. 
1973 "Italy 1830-1914." In The Emergence of Industrial Societies. London: Collins/Fontana. Pp. 279-328.

Cahill, D.

2004 Missionaries on the move: A pastoral history of the Scalabrinians in Australia and Asia, 1952-2002. New York: Center for Migration Studies.

Camera di Commercio Italiana nel Belgio.

1913 Atti del Secondo Congresso delle Camere di Commercio Italiane all'Estero, Bruxelles: 2125 Ottobre 1912. Bruxelles: Tipografia Luigi Bendotti.

Cannistraro, P., and G. Rosoli

1979 Emigrazione, chiesa e fascismo. Lo scioglimento dell'opera Bonomelli (1922-28). Roma: Studium.

Cavagnari, V. W.

1893 La Giuria dell'Esposizione Italo-Americana, Genova 1892. Relazione. Genova: Tipografia del R. Istituto Sordo-Muti.

Cerase, F. P.

1974 "Expectations and Reality: A Case Study of Return Migration from the United States to Southern Italy," International Migration Review, 8: 245-62.

Chan, S.

1990 "European and Asian Immigration into the United States in Comparative Perspective, 1820s to 1920s." In Immigration Reconsidered: History, Sociology, and Politics. Ed. V. Yans-McLaughlin. New York and Oxford: Oxford University Press.

Choate, M. I.

2003 "From Territorial to Ethnographic Colonies and Back Again: The Politics of Italian Expansion, 1890-1912," Modern Italy: Journal of the Association for the Study of Modern Italy, 8: 65-75.

2007 "Identity Politics and Political Perception in the European Settlement of Tunisia: The French Colony vs. the Italian Colony," French Colonial History 7: 97-109.

2008 Emigrant Nation: The Making of Italy Abroad. Cambridge, Massachusetts: Harvard University Press, forthcoming.

(C) 2006 Mark I. Choate. All Rights Reserved. 
Cohen, L.

1990 Making a new deal: industrial workers in Chicago, 1919-1939. Cambridge [England] ; New York: Cambridge University Press.

Commissariat General Italien de I'Emigration, ed.

1925 Conference internationale de l'emigration et de l'immigration. Rome 15-31 mai 1924. Rome: Imprimerie de la Chambre des Députés.

Commissariato dell'Emigrazione.

1903-1909 Emigrazione e colonie. Raccolta di rapporti dei rr. agenti diplomatici e consolari. Roma: Tip. Nazionale di G. Bertero \& C.

1926 Annuario statistico della Emigrazione Italiana dal 1876 al 1925, con notizie sull'emigrazione negli anni 1869-75. Roma: Commissariato Generale dell'Emigrazione.

Committee on Migration, Refugees and Demography

1999 Links between Europeans living abroad and their countries of origin, Parliamentary Assembly of the Council of Europe

Confessore, O.P.

1971 Conservatorismo politico e riformismo religioso. La Rassegna nazionale dal 1898 al 1908. Bologna.

Cordasco, F.

1980 Italian Mass Emigration: The Exodus of a Latin People. A Bibliographical Guide to the Bollettino dell'Emigrazione 1902-1927. Totowa, New Jersey: Rowan and Littlefield.

Corradini, E.

1923 "L'emigrazione italiana nell'America del Sud (1909)." In Discorsi politici (1902-1923). Firenze: Vallecchi.

D'Agostino, P. R.

2004 Rome in America: Transnational Catholic Ideology from the Risorgimento to Fascism. Chapel Hill: University of North Carolina Press.

d'Azeglio, M.

1867 I miei ricordi. Firenze: G. Barbèra.

De Caro, G.

1970 Gaetano Salvemini. Torino: UTET.

(C) 2006 Mark I. Choate. All Rights Reserved. 
De la Garza, R. O., and H. Pachon.

2000 Latinos and U.S. foreign policy: Representing the "homeland"? Lanham, Md.: Rowman \& Littlefield Publishers.

de Luna Martínez, J.

2005 Workers' Remittances to Developing Countries: A Survey with Central Banks on Selected Public Policy Issues, World Bank, Washington

De Mauro, T.

1970 Storia linguistica dell'Italia unita. Bari: Editori Laterza.

De Rosa, L.

1980 Emigranti, capitali e banche (1896-1906). Napoli: Edizione del Banco di Napoli.

Department for International Development (DFID), United Kingdom

2005 Sending Money Home? A Survey of Remittance Products and Services in the United Kingdom. [London]: Profile Business Intelligence.

Diner, $\mathrm{H}$.

2000 "History and the Study of Immigration: Narratives of the Particular." In Migration Theory: Talking across Disciplines. Ed. C. B. Brettell and J. F. Hollifield. New York and London: Routledge. Pp. 27-42.

Direzione Generale della Statistica.

1899 Statistica della Emigrazione Italiana Avvenuta nel 1897. Roma: Tipografia Nazionale di G. Bertero.

1901-1904 Censimento della popolazione del Regno d'Italia al 10 febbraio 1901. Roma: Tipografia Nazionale di G. Bertero.

1904 Statistica della Emigrazione Italiana per l'Estero negli anni 1902 e 1903. Roma: Tipografia Nazionale di G. Bertero.

Direzione generale della statistica.

1908 Annuario Statistico italiano, 1905-1907. Roma: Tip. Nazionale di G. Bertero e C.

Einaudi, L.

1900 Un principe mercante. Studio sulla espansione coloniale italiana. Torino: Fratelli Bocca.

(C) 2006 Mark I. Choate. All Rights Reserved. 
Enriquez, S.

2005 “Mexican Hopefuls Eye Voters in L.A." In Los Angeles Times, 22 August 2005, p. A1

Esposizione Generale Italiana.

1899 Gli italiani all'estero (emigrazione, commerci, missioni). Torino: Tipografia Roux Frassati.

Evans, P. B.

1985 "Transnational Linkages and the Economic Role of the State: An Analysis of Developing and Industrialized Nations in the Post-World War II Period." In Bringing the State Back In. Ed. P. B. Evans, D. Rueschemeyer, and T. Skocpol. Cambridge: Cambridge University Press. Pp. 192-226.

Filipuzzi, A., ed.

1976 Il dibattito sull'emigrazione. Polemiche nazionali e stampa veneta, 1861-1914. Firenze: Felice Le Monnier.

Finkelstein, M. S.

1988 "The Johnson Act, Mussolini and Fascist Emigration Policy, 1921-1930," Journal of American Ethnic History, 8: 38-55.

Foerster, R. F.

1919/1968 The Italian Emigration of Our Times. New York: Russell \& Russell.

Foner, N.

1997 "What's New about Transnationalism? New York Immigrants Today and at the Turn of the Century," Diaspora, 6: 355-75.

2000 From Ellis Island to JFK: New York's Two Great Waves of Immigration. New Haven: Yale University Press.

Fredrickson, G. M.

1995 "From Exceptionalism to Variability: Recent Developments in Cross-National Comparative History," Journal of American History, 82: 587-604.

Frescura, B.

1907 Diplomi e Medaglie assegnate dalla Giuria con le relative motivazioni. Milano: Libreria Fratelli Bocca.

Gabaccia, D. R.

2000 Italy's many diasporas. Seattle: University of Washington Press.

(C) 2006 Mark I. Choate. All Rights Reserved. 
Gerstle, G.

1997 "Liberty, coercion, and the making of Americans," The Journal of American History, 84: 524-58.

Glick Schiller, N.

1999 "Transmigrants and Nation-States: Something Old and Something New in the U.S. Immigrant Experience." In The Handbook of International Migration: The American Experience. Ed. C. Hirschman, P. Kasinitz, and J. De Wind. New York: Russell Sage Foundation. Pp. 94-119.

Glick Schiller, N., L. Basch, and C. Blanc-Szanton, eds.

1992 Towards a Transnational Perspective on Migration: Race, Class, Ethnicity, and Nationalism Reconsidered. New York: New York Academy of Sciences.

Graham, P. M.

1997 "Reimagining the Nation and Defining the District: Dominican Migration and Transnational Politics." In Caribbean Circuits: New Directions in the Study of Caribbean Migration. Ed. P. R. Pessar. New York: Center for Migration Studies. Pp. 91-125.

Gribaudi, P.

1913 La più grande Italia. Notizie e letture sugli Italiani all'estero e sulle colonie italiane (Libia, Eritrea, Somalia). Torino: Lib. edit. Internazionale.

Guarnizo, L. E.

1998 "The Rise of Transnational Social Formations: Mexican and Dominican State Responses to Transnational Migration," Political Power and Social Theory, 12: 45-94.

2001 "On the Political Participation of Transnational Migrants: Old Practices and New Trends." In E Pluribus Unum? Ed. G. Gerstle and J. Mollenkopf. New York: Russell Sage. Pp. 21367.

2003 "The Economics of Transnational Living," International Migration Review, 37: 666-99.

Guarnizo, L. E., and M. P. Smith.

1998 "The Locations of Transnationalism." In Transnationalism from Below. Ed. M. P. Smith and L. E. Guarnizo. New Brunswick, New Jersey: Transaction. Pp. 3-34.

Habermas, J.

(c) 2006 Mark I. Choate. All Rights Reserved. 
1989 The Structural Transformation of the Public Sphere: An Inquiry into a Category of Bourgeois Society. Cambridge, Massachusetts: The MIT Press.

International Monetary Fund.

2005 World Economic Outlook, April 2005: Globalization and External Imbalances. Washington: International Monetary Fund.

ISTAT - Istituto centrale di statistica.

1976 Sommario di statistiche storiche italiane 1861-1975. Roma: Istituto Centrale di Statistica.

1958 Sommario di statistiche storiche italiane 1861-1955. Roma: Istituto Poligrafico dello Stato.

Italian Colonial Institute.

1910 Atti del primo congresso degli italiani all'estero (ottobre 1908). Roma: Cooperativa Manuzio.

1911a. Annuario dell'Italia all'estero e delle sue colonie. Roma: Tipografia dell'Unione editrice.

1911b Atti del Secondo Congresso degli Italiani all'Estero (11-20 giugno 1911). Roma:

Tipografia Editrice Nazionale.

Itzigsohn, J.

2000 "Immigration and the Boundaries of Citizenship: The Institutions of Immigrants' Political Transnationalism," International Migration Review, 34: 1126-54.

Jacobson, M. F.

1995 Special Sorrows: The diasporic imagination of Irish, Polish, and Jewish immigrants in the United States. Cambridge, Massachusetts: Harvard University Press.

Jones-Correa, M.

1998 Between two nations: The political predicament of Latinos in New York City. Ithaca, New York: Cornell University Press.

2001 "Under Two Flags: Dual Nationality in Latin America and Its Consequences for Naturalization in the United States," International Migration Review, 35: 997-1029.

(c) 2006 Mark I. Choate. All Rights Reserved. 
Kennedy, P. M.

1987 The Rise and Fall of the Great Powers: Economic Change and Military Conflict from 1500 to 2000. New York: Random House.

Levitt, $\mathrm{P}$.

1998 "Social remittances: Migration driven local-level forms of cultural diffusion," The International Migration Review, 32: 926-48.

2001a "Transnational migration: taking stock and future directions," Global Networks, 1: 195207.

2001b The transnational villagers. Berkeley: University of California Press.

Levitt, P., and R. de la Dehesa.

2003 "Transnational migration and the redefinition of the state: Variations and explanations," Ethnic and Racial Studies, 26: 587-611.

Light, I., et al.

1994 "Beyond the Ethnic Enclave Economy," Social Problems, 41: 65-80.

Lopez-Guerra, C.

2005 "Should Expatriates Vote?," Journal of Political Philosophy, 13: 216-34.

Loria, L.

1912 "Due parole di programma," Lares: Bullettino Sociale, 1: 9-24.

Louie, $A$.

2000 "Re-territorializing transnationalism: Chinese Americans and the Chinese motherland," American Ethnologist, 27: 645-69.

Mahler, S. J.

2000 "Constructing International Relations: The Role of Transnational Migrants and Other Non-state Actors," Identities, 7: 197-232.

Marcelli, E.A.and B.L. Lowell.

2005 "Transnational Twist: Pecuniary Remittances and Socioeconomic Integration among Authorized and Unauthorized Mexican Immigrants in Los Angeles County." International Migration Review, 39(1): 69-102.

(C) 2006 Mark I. Choate. All Rights Reserved. 
Massey, D. S.

1999 "International Migration at the Dawn of the Twenty-First Century: The Role of the State," Population and Development Review, 25: 303-22.

Miller, M. J.

1981 Immigrants in Europe: An Emerging Political Force. New York: Praeger.

Milza, P.

1981 Italiens et français à la fin du XIXe siècle. Rome: École française de Rome.

Ministero degli affari esteri, Ministero di agricoltura industria e commercio.

1884 Censimento degli Italiani all'estero (dicembre 1881). Roma: C. Verdesi \& C.

Morawska, E.

2001 "Immigrants, transnationalism, and ethnicization: a comparison of this great wave and the last." In E Pluribus Unum? Ed. G. Gerstle and J. Mollenkopf. New York: Russell Sage.

2003 "Disciplinary agendas and analytic strategies of research on immigrant transnationalism: Challenges of interdisciplinary knowledge," The International Migration Review, 37: 61140.

Mozzarelli, C., S. Nespor.

1985 "Amministrazione e mediazione degli interessi: le Camere di commercio." In L'amministrazione nella storia moderna. Milano: Giuffrè. Pp. 1649-706.

Niño Rodríguez, A.

2002 "Políticas de asimilación y de preservación de la nacionalidad de los emigrantes. Españoles en Francia, 1900-1936," Hispania, 62, 2: 433-82.

Nitti, F. S.

1888/1958 "L'emigrazione ed i suoi avversari." In Scritti sulla questione meridionale. Bari: Laterza.

1896 La nuova fase della emigrazione d'Italia. Torino: Roux Frassati e C.

$\varnothing$ stergaard-Nielsen, E., ed.

2003 International migration and sending countries: Perceptions, policies, and transnational relations. Basingstoke and New York: Palgrave Macmillan.

(C) 2006 Mark I. Choate. All Rights Reserved. 
Ostuni, M. R.

1978 "Il fondo archivistico del Commissariato generale dell'emigrazione," Studi emigrazione, 15: 411-40.

2001 "Leggi e politiche di governo." In Storia dell'emigrazione italiana. Ed. P. Bevilacqua, A. De Clementi, and E. Franzina. Roma: Donzelli.

Penne, G. B.

1906 Per I'Italia africana. Studio critico. Roma: Enrico Voghera editore.

Pessar, P. R., ed.

1988 When borders don't divide: Labor migration and refugee movements in the Americas. New York: Center for Migration Studies.

1995 A Visa for a Dream: Dominicans in the United States. Boston: Allyn and Bacon.

Portes, A.

1995 "Children of immigrants: Segmented assimilation and its determinants." In The economic sociology of immigration: Essays on networks, ethnicity, and entrepreneurship. New York: Russell Sage Foundation. Pp. 248-79.

1998 "Social capital: Its origins and applications in modern sociology," Annual Review of Sociology, 24: 1-24.

2001 "Introduction: the debates and significance of immigrant transnationalism," Global Networks, 1: 181-93.

2003 "Conclusion: Theoretical Convergencies and Empirical Evidence in the Study of Immigrant Transnationalism," International Migration Review, 37: 874-93.

Portes, A., L. E. Guarnizo and W. J. Haller.

2002 "Transnational Entrepreneurs: An Alternative Form of Immigrant Economic Adaptation," American Sociological Review, 67: 278-98.

Portes, A., and L. Jensen.

1987 "What's an Ethnic Enclave? The Case for Conceptual Clarity," American Sociological

(C) 2006 Mark I. Choate. All Rights Reserved. 
Review, 52: 768-71.

Roosevelt, T.

1897 American Ideals and other essays, social and political. New York and London: G. P. Putnam's Sons, The Knickerbocker Press.

Rosenblum, M. R.

2003 "The intermestic politics of immigration policy: Lessons from the Bracero Program," Political Power and Social Theory, 16: 139-82.

Rosoli, G.

1996 Insieme oltre le frontiere: momenti e figure dell'azione della Chiesa tra gli emigrati italiani nei secoli XIX e XX. Caltanissetta: S.Sciascia.

,---- ed

1999 Geremia Bonomelli e il suo tempo. Brescia: Fondazione Civiltà Bresciana.

Russell, S. S.

1986 "Remittances from International Migration: A Review in Perspective," World Development, 14: 677-96.

Samama, N.

1910 Contributo allo studio della doppia cittadinanza nei riguardi del movimento migratorio. Firenze: Enrico Ariani.

Scalabrini, G. B.

1899 "L'Italia all'estero." In Gli italiani all'estero (emigrazione, commerci, missioni). Ed. Esposizione Generale Italiana - Esposizione delle Missioni. Torino: Tipografia Roux Frassati. Pp. 21-39.

1997 "L'emigrazione italiana in America. Osservazioni." In Scalabrini e le migrazioni moderne: scritti e carteggi. Ed. S. Tomasi and G. Rosoli. Torino: Società editrice internazionale. Pp. xxi, 322.

1888 Il disegno di legge sulla Emigrazione italiana. Osservazione e proposte. Piacenza: Tipografia dell'Amico del Popolo.

Schmitter, B.

1984 "Sending States and Immigrant Minorities - the Case of Italy," Comparative Studies in Society and History, 26: 325-34.

(c) 2006 Mark I. Choate. All Rights Reserved. 
Schmitter Heisler, B.

1985 "Sending Countries and the Politics of Emigration and Destination," International Migration Review, 19: 469-84.

Seeley, J. R.

1883 The Expansion of England. London.

Sharma, A.

2003 "Come home, we need you," Far Eastern Economic Review (Hong Kong), 166: 28-31.

Smith, R. C.

1997 "Transnational Migration, Assimilation, and Political Community." In The City and the World: New York's Global Future. Ed. M. E. Crahan, A. Vourvoulias-Bush. New York: Council on Foreign Relations. Pp. 110-32.

1998a "Reflections on Migration, the State, and the Construction, Durability and Newness of Transnational Life," Soziale Welt. Sonderband, 12: 197-217.

1998b "Transnational Localities: Community, Technology and the Politics of Membership within the Context of Mexico and U.S. Migration." In Transnationalism from Below. Ed. M. P. Smith and L. E. Guarnizo. New Brunswick, New Jersey: Transaction. Pp. 196-238.

2003a "Migrant Membership as an Instituted Process: Transnationalization, the State and the Extra-Territorial Conduct of Mexican Politics," International Migration Review, 37: 297343.

2003b "Diasporic Memberships in Historical Perspective: Comparative Insights from the Mexican, Italian and Polish Cases," International Migration Review, 37: 724-60.

Soldaini, V.

1969 "La raccolta delle rimesse degli emigrati italiani e l'opera del Banco di Napoli: 19021913," Revue internationale d'histoire de la banque, 2: 137-88.

Soldani, S., and G. Turi.

1993 "Introduzione." In Fare gli italiani: Scuola e cultura nell'Italia contemporanea. Ed. S. Soldani and G. Turi. Bologna: II Mulino. Pp. 9-33.

(c) 2006 Mark I. Choate. All Rights Reserved. 
Speranza, G. C.

1974 "Political Representation of Italo-American Colonies in the Italian Parliament." In The Italians: Social Backgrounds of An American Group. Ed. F. Cordasco and E. Bucchioni. Clifton, New Jersey: Augustus M. Kelley.

Steller, T.

2002 "Mexico is courting its citizens abroad." In The Arizona Daily Star (Tucson, Arizona), 18 April 2002.

Tomasi, L., P. Gastaldo and T. Row, eds.

1994 The Columbus People: Perspectives in Italian Immigration to the Americas and Australia. New York: Center for Migration Studies, Fondazione Giovanni Agnelli.

Tomasi, L. F.

1972 The Italian in America: the progressive view, 1891-1914. New York: Center for Migration Studies.

Tomasi, S. M.

1972 "Americanizzazione o pluralismo? La Chiesa etnica italiana come istituzione mediatrice nel processo d'integrazione degli emigrati negli Stati Uniti d'America." In Gli Italiani negli Stati Uniti. L'emigrazione e I'opera degli italiani negli Stati Uniti d'America. Atti del III Symposium di Studi Americani. Firenze, 27-29 maggio 1969. Firenze: Istituto di studi americani, Università degli studi di Firenze. Pp. 389-422.

1975 Piety and Power: The Role of the Italian Parishes in the New York Metropolitan Area, 1880-1930. New York: Center for Migration Studies.

1983 "Scalabriniani e mondo cattolico di fronte all'emigrazione italiana (1880-1940)." In Gli italiani fuori d'Italia. Gli emigrati italiani nei movimenti operai dei paesi d'adozione 1880-1940. Ed. B. Bezza. Milano: Fondazione Brodolini. Pp. 145-61.

1989 "Scalabrini e i vescovi nordamericani." In Scalabrini tra vecchio e nuovo mondo. Atti del Convegno Storico Internazionale (Piacenza, 3-5 dicembre 1987). Ed. G. Rosoli. Roma: Centro Studi Emigrazione. Pp. 453-67.

1991 "Fede e patria: The 'Italica Gens' in the United States and Canada, 1908-1936. Notes for (C) 2006 Mark I. Choate. All Rights Reserved. 
the History of an Emigration Association," Studi Emigrazione, 28: 319-31.

Trincia, L.

2002 Per la fede, per la patria. I Salesiani e l'emigrazione italiana in Svizzera fino alla Prima guerra mondiale. Roma: LAS.

Vaughan, L. J.

1991 "Cosmopolitanism, Ethnicity, and American Identity: Randolph Bourne's 'Trans-National America'," Journal of American Studies, 25: 443-59.

Vecoli, R. J.

1995 "The Italian Diaspora, 1876-1976." In The Cambridge Survey of World Migration. Ed. R. Cohen. Cambridge: Cambridge University Press. Pp. 114-22.

Vertovec, S.

2004 "Migrant Transnationalism and Modes of Transformation," The International Migration Review, 38: 970-1002.

Villari, $\mathrm{P}$.

1901 "Discorso, XII Congresso dei rappresentanti dei comitati a Verona (26-29 September 1901)," Atti della Società "Dante Alighieri" per la lingua e per la cultura italiana fuori del regno. Bollettino Trimestrale: 3-18.

Whelpley, J. D.

1905 The Problem of the Immigrant. A brief discussion, with a summary of conditions, laws, and regulations governing the movement of population... London: Chapman \& Hall.

Wimmer, A., N. Glick Schiller.

2003 "Methodological Nationalism, the Social Sciences, and the Study of Migration: An Essay in Historical Epistemology," International Migration Review, 37: 576-611.

Wyman, M.

1993 Round-Trip to America: The immigrants return to Europe, 1880-1930. Ithaca and London: Cornell University Press.

Zolberg, A.R.

2006 A Nation by Design: Immigration Policy in the Fashioning of America. New York, NY and Cambridge, MA: Russell Sage Foundation \& Harvard University Press.

(c) 2006 Mark I. Choate. All Rights Reserved. 
1. Address correspondence to Mark Choate, History Department, Brigham Young University, Provo, Utah 84602-4446; e-mail mark.choate@byu.edu. I thank Lydio Tomasi for suggesting I write this article; the Pew Trusts, Mellon Foundation, and Smith-Richardson Foundation for their financial support; the archives cited below for allowing me access; Ignacio Garcia, Donna Gabaccia, and Emilio Franzina for sharing their ideas on these issues; and Matt Mason, Susan Rugh, and Brett Rushforth for their comments. All textual translations are my own.

2. "Avviso ai Cittadini Italiani Residenti negli Stati Uniti sul Voto all'Estero," http://www.italyemb.org/avviso3.htm, accessed January 2006.

3. "Il voto degli italiani all'estero è legge," Corriere della Sera, 20 December 2001; www.ministeroitalianinelmondo.it (accessed 5/10/05); for precedents, see Atti del primo congresso degli italiani all'estero (ottobre 1908), vol. 2 (Rome, 1910), 2:11-114, 332-333; Archivio Storico della Camera dei Deputati, Incarti di Segreteria, index 1909-1913, s.v. "Colonie Libere": discussion in Chamber of Deputies 22 June 1909, in Senate 30 June-1 July 1909; in Chamber 22 May 1912.

4. See discussion in Atti Parlamentari, Camera dei Deputati, Leg. XXI, 1a sessione, Discussioni, 23 November-3 December 1900, p. 398-963; Senato, 21-29 January 1901, p. 844-1042.

5. Italy was recognized diplomatically and militarily as a Great Power and member of the Triple Alliance, but struggled as the "least of the great." See Kennedy, 1987.

6. Archivio Storico della Camera dei Deputati, Incarti di Segreteria, B. 464, Parlamento 16, 2d session, Progetto di Legge n. 85 (CD), 22 January - 6 December 1888.

7. Luigi Bodio in La Perseveranza, 13 July 1911. Biblioteca Apostolica Vaticana, Carte Villari 6, f. 222v.

8. Alfredo Baccelli, relatore, Atti Parlamentari, Camera dei Deputati, Leg. XXIII, 1a sessione, Discussioni, 11 June 1912, p. 20700.

9. Archivio di Stato di Rovigo, Carte Rossi n. 3, ff. 2-11; see Milza, 1981; Jones-Correa, 1981.

10. Note, for example, the Italian Chamber of Commerce in Montevideo, Uruguay: Archivio Centrale dello Stato, MAIC, Divisione Industria e Commercio b. 477, "Camere di Commercio all'estero. Montevideo. Dal 1883 al 1887."

(c) 2006 Mark I. Choate. All Rights Reserved. 
11. "La Camera di Commercio," L'Indipendente (Montevideo), yr. 1. n. 50, 2 October 1883. ACS, MAIC Div. Ind. e Commercio b. 477.

12. French documentation of the Italian Chamber's activities is in Archives de la Ministère des Affaires Etrangères, Paris, NS Tunisie 385, f. 34-50; see Choate, 2007.

13. For example, Ambassador Rennell Rodd to Marquess of Lansdowne, "Emigration from Italy, 1903-04." Public Record Office, FO 45/903.

14. Speech of President On. Ernesto Artom to Assemblea Generale dei Soci, 30 May 1915, Archivio Storico del Ministero per l'Africa Italiana, pos. 163/2 f. 19.

15. Quoted in "L'Italica Gens," Italica Gens 1, no. 1 (1910): 11.

16. Sidney Sonnino, Foreign Affairs Minister, Direzione Generale delle Scuole italiane all'Estero n. 43 pos. IV, to President of the Società Nazionale "Dante Alighieri" Roma, 22 May 1916, Archivio Storico della Società Dante Alighieri, Sede Centrale, Fasc/1916 A25.

17. Nel Cinquantenario della Camera di Commercio Italiana in New York. 1887-1937-XVI (New York, 1937), xxxix.

18. Archivio Storico del Banco di Napoli, Banco di Napoli Servizio Emigrati Posiz. XIX, 4, 11/2.

19. "International Money Transfer Class Action Settlement involving Western Union, Orlandi Valuta, and Tex Mex," Canada NewsWire, 20 October 2003; "Bank of America phases out money transfer fees to Mexico," Retail Banker International, 28 February 2005; David Fairlamb, "Can Western Union Keep On Delivering?," BusinessWeek International Edition, 22 December 2003, p. 52.

20. "Cronaca: Noticine sulla 1a Esposizione italiana," published by L'Operaio Italiano. Archivio Centrale dello Stato, MAIC Div Ind e Commercio b. 83; "Esposizione Italiana in Londra 1888." Giornale della Camera di Commercio Italiana in Londra 1, no. 14 (1887 November - June 1888).

(c) 2006 Mark I. Choate. All Rights Reserved. 